\title{
Tourism affects the behavioural budget of the common dolphin Delphinus sp. in the Hauraki Gulf, New Zealand
}

\author{
Karen A. Stockin ${ }^{1, *}$, David Lusseau ${ }^{2}$, Vicky Binedell ${ }^{1}$, Nicky Wiseman ${ }^{3}$, \\ Mark B. Orams ${ }^{1}$ \\ ${ }^{1}$ Coastal-Marine Research Group, Institute of Natural Resources, Massey University, Private Bag 102-904, \\ North Shore MSC, New Zealand \\ ${ }^{2}$ Biology Department, Dalhousie University, Halifax, Nova Scotia B3H 4JI, Canada \\ ${ }^{3}$ Laboratory of Molecular Biology and Evolution, University of Auckland, Private Bag 92019, Auckland, New Zealand
}

\begin{abstract}
Common dolphins Delphinus sp. are frequently targeted by tourism operations in New Zealand waters, yet there is a paucity of data on potential impacts faced by this species. Transition matrix models, used widely in population ecology, have recently been applied to behavioural transitions in order to provide successful management guidelines. We detail the use of Markov chain models to assess the impact of tourism activities on the behavioural state of common dolphins in the Hauraki Gulf, New Zealand. First-order time discrete Markov chain models were used to describe transition probabilities in both control and impact scenarios. The effect of boat interactions was quantified by comparing transition probabilities of both control and impact chains. Foraging and resting bouts were significantly disrupted by boat interactions to a level that raises concern about the sustainability of this impact. Both the duration of bouts and the overall time spent in these 2 behavioural states decreased. Foraging dolphins took significantly longer to return to their initial behavioural state in the presence of the tour boat. There was also an increased preference to shift behaviour to socialising or milling after tour boat interactions. Impacts identified in the present study are similar to those previously reported for bottlenose dolphins, a coastal species typically considered to be more susceptible to cumulative anthropogenic impacts.
\end{abstract}

KEY WORDS: Markov-chain models · Dolphin tourism • Common dolphin · Delphinus sp. . Disturbance $\cdot$ Foraging $\cdot$ New Zealand

\section{INTRODUCTION}

A particular form of nature tourism, the viewing of and interaction with marine mammals in the wild, has undergone dramatic growth in recent decades (Hoyt 2001). Interactions between cetaceans and tour boats are increasing, with the number of people involved in cetacean-watching activities exceeding 9 million in 1998 (Hoyt 2001). Alongside such growth, many studies have reported short-term behavioural changes of cetaceans in response to tourism activities from many locations around the world. In New Zealand and Australia alone, such behavioural changes have been observed in a number of cetacean species including the humpback whale Megaptera novaeangliae, sperm whale Physeter macrocephalus, dusky dolphin Lagenorhynchus obscurus, common dolphin Delphinus delphis, Hector's dolphin Cephalorhynchus hectori and bottlenose dolphin Tursiops spp. Responses in different populations include variations in vocalisations, 
increase in dive intervals and aerial behaviours, horizontal avoidance, increase in speed and decrease in resting behaviour (Gordon et al. 1992, Corkeron 1995, Barr \& Slooten 1999, Bejder et al. 1999, Scarpaci et al. 2000, Williams et al. 2002, Lusseau 2003b, Constantine et al. 2004, Bejder et al. 2006b, Neumann \& Orams 2006, Richter et al. 2006). In addition to such responses, there have been longer-term impacts reported including area avoidance and declines in relative abundance (Lusseau 2005, Bejder et al. 2006b).

Recent New Zealand-based research suggests increasing exposure to commercial tourism can be detrimental to coastal species such as bottlenose dolphins (Constantine et al. 2004, Lusseau 2004) and Hector's dolphins (Bejder et al. 1999). The inshore distribution of such species makes them more susceptible to coastal anthropogenic influences, thus placing them at high risk. Typically, common dolphins are a pelagic species within New Zealand waters (Gaskin 1968), and thus considered less at risk from cumulative impacts such as those associated with dolphin tourism.

The study reported here took place in the Hauraki Gulf, New Zealand (Fig. 1), where a population of common dolphins occurs year-round. Based on provisional photo-identification matches between catalogued individuals in the Hauraki Gulf and Mercury Bay, a region $100 \mathrm{~km}$ east of the gulf, this population is currently assumed to be open (Neumann et al. 2002). Dolphin tourism within this area developed relatively recently compared to other regions around New Zealand. The New Zealand Department of Conservation issued the first dolphin tourism permit for the Hauraki Gulf in September 2000. Currently, 2 dedicated dolphin tourism boats operate year-round within the region,

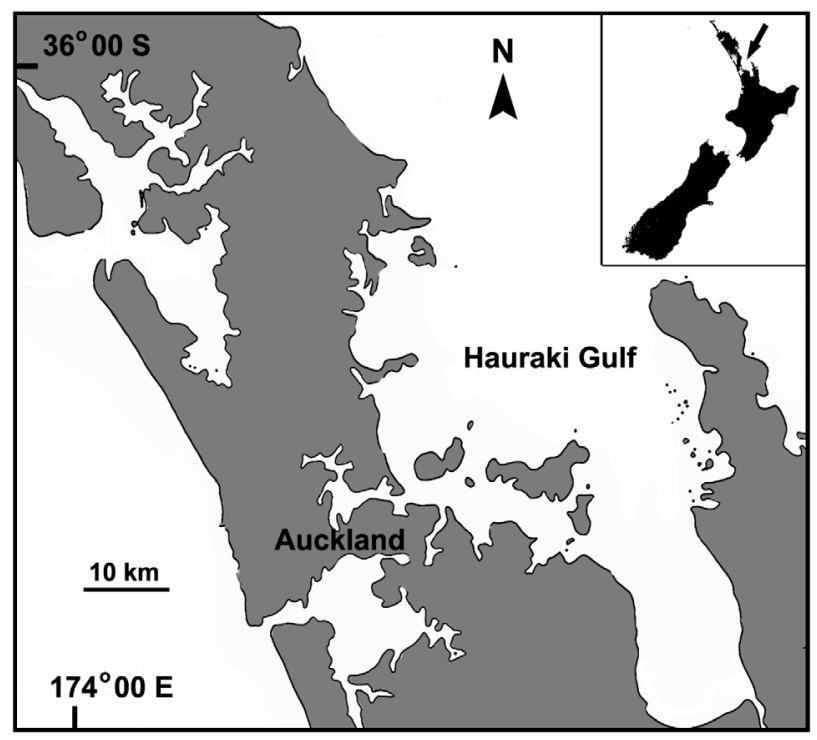

Fig. 1. Location of the Hauraki Gulf, New Zealand although this study was conducted prior to the establishment of the second permit in December 2005 and considers only the effects of 1 tour boat. Under the Marine Mammals Protection Act 1978 and Marine Mammals Protection Regulations 1992, the New Zealand Department of Conservation is charged with ensuring that dedicated dolphin tourism operations do not have a detrimental impact on marine mammals.

We investigated the effects of tourism activities on the behavioural budget of common dolphins in the Hauraki Gulf. Common dolphins are the primary target species for tour boats operating in this region, since their encounter rates remain consistently high year-round (ca. 97\% of trips undertaken). Behavioural activity budgets have been used to assess disturbance in several cetacean species including killer whale Orcinus orca, dusky dolphin, bottlenose dolphin and common dolphin (Barr \& Slooten 1999, Lusseau 2004, Neumann \& Orams 2006, Williams et al. 2006). As with previous tourism studies that have focused on coastal species (e.g. Constantine et al. 2004, Lusseau 2004, Bejder et al. 2006a), we were particularly interested in determining whether tour boat interactions cause variations in the population's activity budget that could have detrimental long-term effects, e.g. decreased foraging opportunities or increased energy expenditures.

\section{MATERIALS AND METHODS}

Study site. Auckland $\left(36^{\circ} 51^{\prime} \mathrm{S}, 174^{\circ} 46^{\prime} \mathrm{E}\right)$ is situated on the North Island and is, with over 1.4 million inhabitants, New Zealand's largest city. Bordering the city's northeastern coastline, the Hauraki Gulf is a shallow semi-enclosed coastal sea extending from Bream Head to Cape Colville, Coromandel Peninsula on the North Island's east coast $\left(36^{\circ} 10^{\prime} \mathrm{S}\right.$ and $\left.36^{\circ} 60^{\prime} \mathrm{S}\right)$. A warm temperate region influenced by the East Auckland Current, the Gulf is an extremely productive ecosystem with high biodiversity, particularly among seabirds and marine mammals (Owen \& Owen 1999). With a maximum depth of just $60 \mathrm{~m}$, the Hauraki Gulf provides a relatively shallow environment for common dolphins, which are typically associated with the deep waters of the continental shelf and beyond (Gaskin 1992). Although the dolphin population is apparently open, the Hauraki Gulf has proven to be an important feeding area for this species (O'Callaghan \& Baker 2002, Burgess 2006), which may explain the yearround occurrence of common dolphins in this region. Resighting rates of known marked individuals within the Hauraki Gulf also suggest that site fidelity for this species is higher in this area than in neighbouring regions (Neumann et al. 2002). 
Marine traffic in the Hauraki Gulf consists of a wide variety of vessels from large commercial ships and fishing boats to ferries, cruise liners, recreational power boats, tour boats, yachts and kayaks. During weekends and public holidays, there is a marked increase in vessel traffic, in particular sailing boats, personal water craft (jet skis) and recreational fishing boats. Here we report the effects of just 1 boat, the only permitted dolphin tour boat operational at the time of the present study. This tour boat operated throughout all seasons, undertaking 1 trip $\mathrm{d}^{-1}$ except during peak summer, when occasionally there were 2 trips $\mathrm{d}^{-1}$.

Data collection. Non-systematic surveys were conducted in the Hauraki Gulf from an independent research boat (5.5 m rigid-hull inflatable with $90 \mathrm{hp}$, 4stroke outboard engine), between February 2003 and January 2005. Once a school of dolphins was detected, the boat was manoeuvred towards the group in a manner that best minimised any effects of the observational platform (Lusseau 2003a). Thus, focal schools were approached from the side and from behind, moving in the same direction as the school. Boat speed and direction matched that of the school, which in the majority of cases was idle speed ( $<5$ knots). Schools were followed at distances ranging from 50 to $200 \mathrm{~m}$, although, where possible, a distance of $50 \mathrm{~m}$ was maintained. In an attempt to minimise our potential disturbance, a 4-stroke engine was chosen for reduced noise and exhaust emissions.

During a follow, the behavioural state of the focal school was determined every 3 min using focal-group scan sampling (Altmann 1974). A school was defined as any number of dolphins engaged in a similar activity, moving in a uniform direction and within 5 bodylengths of each other. The primary activity of the school was determined using behavioural categories modelled on Shane et al. (1986), defined in Table 1. The behavioural state of each focal group was determined by the activity of $>50 \%$ of school members.

Focal schools were sampled to determine the effect of boat interactions at the school, rather than the individual level. Focal-group sampling was used since large schools (typically > 50 dolphins) precluded individual follows (Mann 2000). Observations ended when fuel reserves became low or deterioration in the weather and/or daylight was imminent, thus the end of a sequence of observations was not dependent on the behaviour of the focal school or our ability to observe more discrete behaviours. This protocol was maintained during interactions with the tour boat, and thus the state of the observer boat remained consistent throughout all control and impact scenarios. Consequently, any differences observed related only to the presence of the dolphin tour boat. Boats approaching to within approximately $300 \mathrm{~m}$ of the focal school (as determined by Tasco Offshore $7 \times 50$ reticule binoculars) were deemed as interactions and treated as impact sequences. This distance was consistent with the New Zealand Marine Mammals Protection Regulations 1992.

Markov chains. First developed by Markov (1906), Markov chains have been widely used in population ecology (Senata 1966, Werner \& Caswell 1977, Brault \& Caswell 1993, Fujiwara \& Caswell 2001, Hill \& Caswell 2001). To date, only a handful of tourism impact studies (e.g. Lusseau 2004, Bain et al. 2006, Williams et al. 2006) have applied the principles of such models to conservation behaviour (Blumstein 2004). Since Markov chains quantify the dependence of an event on preceding events, they can be used to provide probabilities of transition from one event to another when mutually exclusive behavioural categories are defined.

Two 2-way contingency tables ('preceding' versus 'succeeding' behavioural states) were developed, as described in Lusseau (2003a). If no tour boat interaction occurred between two behavioural samples, the transition between these 2 samples was tallied in a

Table 1. Delphinus sp. Definitions of behavioural states of common dolphin schools in the Hauraki Gulf, with abbreviations for each state given in parentheses

State Definition

Travel Dolphins engaged in persistent, directional move-

(TR) ment making noticeable headway along a specific compass bearing. School spacing varied and individuals swam with short, relatively constant dive intervals

Rest Dolphins observed in a tight school $(<1$ body

(RE) length between individuals), engaged in slow manoeuvres (slower than the idle speed of the observing boat) with little evidence of forward propulsion. Surfacings appeared slow and were generally more predictable than those observed in other behavioural states

Mill Dolphins exhibited non-directional movement,

(MI) frequent changes in bearing prevented animals from making headway in any specific direction. No net movement. Individuals surfaced facing various directions

Forage Dolphins involved in any effort to pursue, capture

(FOR) and/or consume prey, as defined by observations of fish chasing, co-ordinated deep diving and rapid circle swimming. Prey frequently observed at the surface during the foraging activity of the dolphins

Social Dolphins observed in diverse interactive events

(SO) such as chasing, copulating and/or engaged in any other physical contact with other dolphins (excluding mother-calf pairs). Aerial behaviours such as breaching frequently observed 
control table. If a tour boat interaction occurred between two samples, the transition was tallied in an impact table. As reported in Lusseau (2003a), we removed the transition between a sample succeeding an interaction and the following sample since it was not possible to determine the extent of the potential impact. Control and impact tables were then compared in order to detect the effect of tour boat interactions. A log-linear analysis was applied to assess the independence of the behavioural transitions from boat presence. We used the difference in goodness of fit between the saturated model and the model considering all 2-way interactions to test for the effect of boat presence on the behavioural transitions

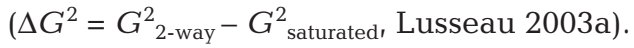

Transition probabilities (from preceding to succeeding behaviour) were determined in both control and impact chains by

$$
p_{i j}=\frac{a_{i j}}{\sum_{j=1}^{5} a_{i j}}, \sum_{j=1}^{5} p_{i j}=1
$$

where $i$ is the preceding behaviour, $j$ is the succeeding behaviour ( $i$ and $j$ range from 1 to 5, because there were 5 behavioural states), $a_{i j}$ is the number of transitions observed from behaviour $i$ to $j$, and $p_{i j}$ is the transition probability from $i$ to $j$ in the Markov chain. Each transition is a proportion of time a succeeding behaviour was observed following a preceding behaviour (Eq. 1). Therefore, the effect of tour boat interactions on the behaviour transition probability matrix was tested using a Z-test for proportions (Fleiss 1981). Each control transition was compared to its impact counterpart. The expected number of transitions it took the dolphins to return to each behavioural state was approximated for both control and impact chains (Higgins \& Keller-McNulty 1995):

$$
E\left(T_{j}\right)=\frac{1}{\pi_{j}}
$$

where $\left(T_{j}\right)$ denotes the time (i.e. number of transitions) it takes to return to state $j$ given that the dolphins are currently in state $j$, and $\pi$ is the steady-state probability of each behaviour in the chain. The expected number of transitions (Eq. 2) was multiplied by the length of each transition unit (i.e. $3 \mathrm{~min}$ ) in order to calculate the average time (min) it took the dolphins to return to each initial behavioural state. These average times were compared between control and impact scenarios in order to assess the effect of tour boat interactions on the behavioural states of the dolphins.

Following the Perron-Frobenius theorem, the behavioural budget in each situation (control and impact) was approximated by the left eigenvector of the dominant eigenvalue of the transitions matrices (Lusseau 2003a). Differences observed in the budget were inherent to interactions with the tour boat. Differences between the 2 behavioural budgets were tested using a binomial Z-test for proportions (Fleiss 1981) and $95 \%$ confidence intervals (CI) were calculated. Finally, the average bout length of each behavioural state, $\overline{t_{i i}}$ was approximated for both chains from the mean of the geometric distribution of $p_{i i}$ (Guttorp 1995) and subsequently compared using the Student's $t$-test.

\section{RESULTS}

\section{Field effort}

During the study period, a total of $86 \mathrm{~h}$ over $46 \mathrm{~d}$ was spent following focal schools. A total of 63 boat interactions were observed, with dolphins spending $28.9 \%$ of the time that they were followed by the observing research boat in the presence of the tour boat. During the study period, 1566 behavioural transitions were recorded, of which 1118 and 448 were considered as control and impact respectively. These transitions were collected over 52 control and 23 impact sequences. Control sequences lasted on average $74.5 \mathrm{~min}($ median $=67.5 \mathrm{~min}, \mathrm{SE}=5.7$, range $=30$ to $210 \mathrm{~min}$ ) and impact sequences averaged $61.4 \mathrm{~min}$ $($ median $=51 \mathrm{~min}, \mathrm{SE}=6.7$, range $=30$ to $150 \mathrm{~min})$. Despite the intensity of vessel traffic in the region, the time dolphins spent interacting with other boats was relatively low when compared with the tour boat. While dolphins spent $28.9 \%$ of the time we spent following them interacting with the tour boat, only $1.8 \%$ of this time was spent interacting with other boats. These interactions also tended to be shorter, lasting on average approximately $20 \mathrm{~min}$. Due to small sample size, all observations of dolphin behaviour with vessels other than the tour boat were excluded from this analysis.

\section{Effect of tour boat interactions}

Tour boat interactions significantly affected behavioural state transitions $\left(\Delta G^{2}=106.6, \mathrm{df}=16, \mathrm{p}<0.001\right)$. While these interactions had an effect on the transitions in behavioural states of common dolphins (Table 2), observed effects did not appear homogeneous throughout all transitions. Overall, the presence of the tour boat significantly changed 3 transitions (Fig. 2). The likelihood of staying foraging, when foraging, was significantly decreased by $6.9 \%$ in the presence of the tour boat $(Z=-1.82, \mathrm{p}<0.001)$. Meanwhile, transitions Mill $\rightarrow$ Social $(Z=2.42, \mathrm{p}=0.0015)$ and Social $\rightarrow$ Mill $(Z=2.67, \mathrm{p}=0.008)$ both signifi- 
Table 2. Delphinus sp. Probability of being in a particular behavioural state $\pi_{\mathrm{j}}$, average number of time units taken to return to a behavioural state $E\left(T_{j}\right)$, and average time (min) required to return to a behavioural state once boat has approached; during control (presence of research boat only) and impact (presence of tour and research boat) scenarios. See Table 1 for definitions of behavioural states

\begin{tabular}{|lcrc|}
\hline Behaviour & $\pi_{\mathrm{j}}$ & $E\left(T_{j}\right)$ & $\begin{array}{c}\text { Behavioural state } \\
\text { resumed }\end{array}$ \\
\hline Control & & & \\
Travel & 0.316 & 3.2 & 9.5 \\
Mill & 0.223 & 4.5 & 13.5 \\
Forage & 0.335 & 3.0 & 9.0 \\
Rest & 0.057 & 17.5 & 52.6 \\
Social & 0.069 & 14.5 & 43.4 \\
Impact & & & \\
Travel & 0.347 & 2.9 & 8.6 \\
Mill & 0.279 & 3.6 & 10.7 \\
Forage & 0.216 & 4.6 & 13.9 \\
Rest & 0.054 & 18.6 & 55.7 \\
Social & 0.104 & 9.6 & 28.9 \\
\hline
\end{tabular}

cantly increased when the tour boat interacted with dolphins (Fig. 2). In most cases where an increase in transition probability was detected, Mill was the succeeding behavioural state (Fig. 2). The probability of remaining in a resting state ( $\mathrm{p}_{\text {rest-rest }}$ ) also decreased by $2.7 \%$ in the presence of the tour boat.

The average time taken for dolphins to return to their initial behavioural state altered in the presence of the tour boat. Generally, foraging and resting dolphins

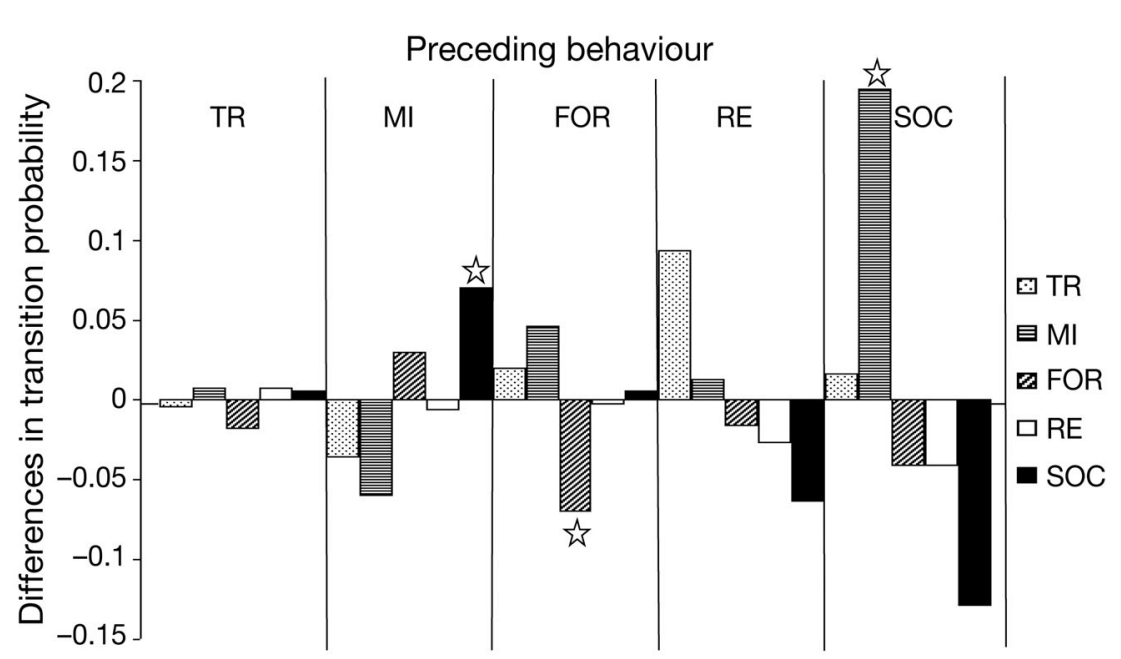

Fig. 2. Delphinus sp. Effect of boat interactions on transitions in behavioural state of dolphins, based on differences in transition probabilities ( $\mathrm{p}_{\mathrm{ij}(\mathrm{impact})}$ -

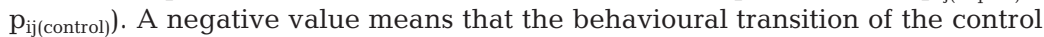
chain is superior to that of the impact chain. The graph is composed of 5 parts, one for each preceding behavioural state, separated by vertical lines. In each part, bars correspond to succeeding behavioural states (see key). Transitions with a significant difference $(\mathrm{p}<0.05)$ are indicated with a star. See Table 1 for definitions of behavioural states took longer to return to their initial behavioural state in the presence of the tour boat, with the time required to return to foraging activity extending by $54 \%$ to 13.9 min (Table 2). The average bout length varied considerably between control and impact scenarios (Table 3). Bout length for foraging dolphins decreased significantly by $4.0 \mathrm{~min}$ (95\% CI: 3.9 to 4.1 ; $t=108.67, \mathrm{p}<$ 0.001 , df $=225$ ) in the presence of the tour boat. Bout length also decreased significantly by $1.5 \mathrm{~min}$ for socialising dolphins (95\% CI: 1.4 to $1.7 ; t=17.83$, p < 0.001 , df $=89$ ). The behavioural budget of common dolphins was different when tour boat interactions occurred (Fig. 3). Overall, dolphins spent more time travelling, milling and socialising when the tour boat was present, to the detriment of foraging and resting states. Significantly, the time spent foraging was reduced in the presence of the tour boat by $11.9 \%$ (95\% CI: 7.2 to $16.6 \% ; Z=4.95$, p < 0.001 ).

\section{DISCUSSION}

The growth of cetacean-based tourism in New Zealand has been relatively recent. For example, watching sperm whales in Kaikoura did not start until 1987 (Donoghue 1996) and dolphin-based tourism only appeared in the 1990s. Growth has been extensive and to date over 80 cetacean-based tourism permits have been issued in New Zealand, most of them for dolphin watching and/or swimming (New Zealand Department of Conservation, unpubl. data). This industry generated an estimated \$NZ 24.6 million for the New Zealand economy in the year ending December 2006 (WWF New Zealand, unpubl. data). With approximately 103000 international visitors participating in dolphin-tourism during the same period (New Zealand Ministry of Tourism, unpubl. data), it is clear that this industry has become an important 'selling point' used by the New Zealand Ministry of Tourism to attract overseas visitors (Orams 2003).

While many view and promote whale and dolphin watching as a sustainable 'use' of marine mammals, there is widespread and growing concern over the potential impacts associated with this tourism activity (Australasian examples alone include Gordon et al. 1992, Constantine 2001, Lusseau 2003b, Scarpaci et al. 2003, Constantine et al. 2004, Orams 2004). Our study provides additional evidence that supports the concerns 
Table 3. Delphinus sp. Average bout length $\overline{t_{i i}}$ during control (presence of research boat only) and impact (presence of tour and research boats) scenarios. See Table 1 for definitions of behavioural states

\begin{tabular}{|c|c|c|}
\hline \multirow{2}{*}{ Behaviour } & \multirow[b]{2}{*}{ Control } & \multirow[b]{2}{*}{ Impact } \\
\hline & & \\
\hline Travel & 5.31 & 5.20 \\
\hline Mill & 3.38 & 2.96 \\
\hline Forage & 9.84 & 5.85 \\
\hline Rest & 3.50 & 3.20 \\
\hline Social & 4.29 & 2.76 \\
\hline
\end{tabular}

expressed by these authors. As with many previous studies, we found significant changes in behaviour of the dolphins as a consequence of tour boat interactions. Our transition analyses using Markov chains showed that tour boat approaches and interactions significantly changed the behavioural state of common dolphins in the Hauraki Gulf. More specifically, the common dolphins targeted for tourism in this region were significantly less likely to continue foraging and less likely to continue resting after the approach of the tour boat.

Given that dolphins spent $28.9 \%$ of their time interacting with the tour boat, their overall behavioural budget (compiled from the time spent in control [71.1\%] and impact [28.9\%] situations) did not change significantly compared to their control behavioural budget. However, it is worth noting that the amount of time they spent foraging overall was lower by $10 \%$ compared to their control budget (proportion of time

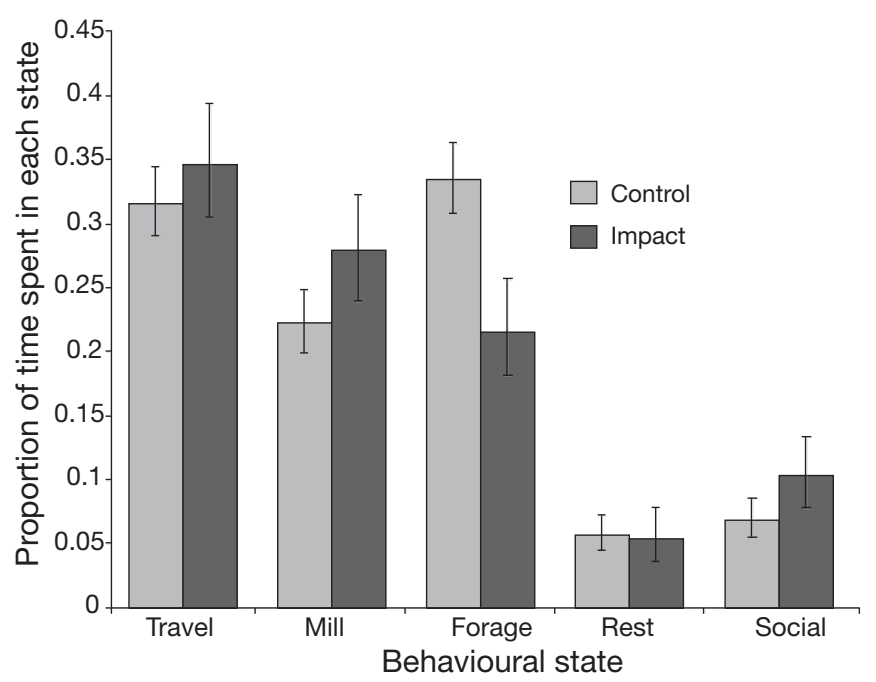

Fig. 3. Delphinus sp. Effect of boat interactions on the behavioural budget of common dolphins in the Hauraki Gulf. Proportion of time spent in each behavioural state depending on the presence of the tour boat (control: research boat only, impact: tour and research boats). Means $\pm 95 \% \mathrm{CI}$ spent foraging, control budget: $33.5 \%$ [95\% CI: 30.8 to $36.3 \%$ ], overall budget: $30 \%$ [95\% CI: 27.9 to $32.4 \%$ ]). The difference between these two proportions would become significant were dolphins to spend at least $31 \%$ of their time interacting with tour boats (i.e. a $5 \%$ increase in tourism activity). The confidence intervals of these two proportions would no longer overlap were dolphins to spend at least $40 \%$ of their time interacting with tour boats (i.e. a $38 \%$ increase in tourism activities). Since a second permit has already been issued for this region, it is likely these threshold levels have been reached, if not surpassed.

Changes in the duration of foraging bouts and other critical aspects of the dolphins' behavioural budget following tour boat interactions illustrate impacts that may have important long-term implications for a population. Foraging and subsequent feeding are critical components of any predator's behavioural repertoire, and disturbance or disruption can have major consequences (Boggs 1992, Williams et al. 2006). Dolphin foraging and feeding behaviours are thought to have evolved in the context of the local ecosystem (Würsig 1986). The foraging behaviour of this species within the Hauraki Gulf has recently been shown to be important not only for the dolphins, but also for species such as the Australasian gannet Morus serrator and Bryde's whale Balaenoptera brydei (Burgess 2006). These species forage predominantly in association with common dolphins and appear, at least in part, to rely on common dolphins for prey detection (Burgess 2006). Similar mixed-species feeding associations have been observed in other locations (Clua \& Grosvalet 2001, Neumann \& Orams 2003) and are similar to those previously documented between dolphins Stenella spp., yellowfin tuna Thunnus albacares and seabirds in the eastern tropical Pacific (Gerrodette \& Forcada 2005). Thus, disruption of foraging and feeding behaviours of common dolphins in the Hauraki Gulf has significant implications not only for the dolphins, but also potentially for other apex predators that may feed in association.

The disruption of resting could also have important implications, although disturbance of resting activity during daylight hours is arguably less problematic than the disruption of foraging. Activity budgets compiled by Neumann (2001a) for common dolphins in Mercury Bay, New Zealand showed that only a small proportion $(0.7 \%)$ of daylight hours was spent resting. It is therefore assumed that most resting occurs at night, although no empirical data are available to substantiate this proposal. Two possible inferences can be made about disturbance of resting by the tour boat. First, since common dolphins spend such a small proportion of their time resting during daylight, it can be assumed that this is not a critical part of their daytime 
activities. Thus, change from resting to other behavioural states as a consequence of the presence of the tour boat is unlikely to be disadvantageous. Second and conversely, because so little time is spent resting during the day, this limited time is important and thus any disturbance could be potentially detrimental. Regardless of the validity of these inferences, it is clear that tourism activity focused on common dolphins in the Hauraki Gulf does have impacts on their behaviour. Furthermore, it is possible that such impacts, particularly any disruption to foraging activities, could have detrimental long-term consequences for this population. This is considered more likely than in neighbouring regions where tourism impacts have been identified (Neumann \& Orams 2006) but where occurrence of common dolphins is strictly seasonal (Neumann 2001b) and site fidelity is comparatively low (Neumann et al. 2002). The selective consequences of reducing fitness on some portion of populations (either through harvesting, or energetic impacts) are thought to have large-scale influences on the ecology and evolution of that population (Coltman et al. 2003). Therefore, tourism can, like any selective harvesting (even non-consuming), affect the biology and ecology of the whole population through its effects on susceptible individuals i.e. dolphins that frequently encounter the tour boat as a consequence of higher site fidelity.

\section{CONCLUSIONS}

Since common dolphins are the most abundant cetaceans in the Hauraki Gulf (O'Callaghan \& Baker 2002), they remain the primary target species of both tour boats currently operating in the area. As such, common dolphins form the economic crux of the marine mammal tourism industry in this region. Bryde's whales are targeted by the same tour boats in the Hauraki Gulf, although to a lesser extent owing to their seasonal occurrence (O'Callaghan \& Baker 2002). While inshoreoffshore movements of common dolphins have been recorded elsewhere in New Zealand (Neumann 2001b), this species occurs within the Hauraki Gulf yearround (O'Callaghan \& Baker 2002). The significance of these waters for feeding (Burgess 2006) and the occurrence of neonates and calves throughout much of the austral spring and summer (Schaffar-Delaney 2004) further highlight the importance of the Hauraki Gulf for this particular population. It can be concluded from the present study that even low-level tourism based on common dolphins in the Hauraki Gulf is not benign and that continued operation of dolphin tourism in this area needs to be carefully monitored. This is particularly important given the recent introduction of a second dolphin tour boat operating within this region.
From a management perspective, several possible mitigating measures should be considered. Firstly, tour boats could be prohibited from approaching common dolphins when they are actively foraging or feeding. An implication of this approach would be the training of tour boat skippers to ensure successful identification of foraging and feeding activity from a distance. However, in order to fully determine the dolphins' behavioural state, tour boats may on occasion have to approach within a range that could still influence behaviour. Alternatively, another option would be to identify the time and/or location at which dolphins are more likely to be foraging and to prevent tour boat interactions during these periods and/or in those locations (Higham \& Lusseau 2004).

The Hauraki Gulf has been identified as a marine ecosystem of national significance (Owen \& Owen 1999). In addition, the New Zealand Marine Mammals Protection Act 1978 clearly states that tourism operations should not have a detrimental impact on marine mammals. This study reports detrimental impacts on common dolphins experiencing relatively low-levels of tourism. This is not the first study to show important detrimental impacts associated with low-level dolphin tourism. In Shark Bay, Australia Bejder et al. (2006b) identified significant long-term impacts as a result of increasing tourism by 1 to just 2 tour boats. As observed by Bejder et al. (2006b), it is likely that the disturbance shown in this study from only 1 tour boat will have been exacerbated by the recent expansion of dolphin tourism in this region.

Our findings suggest tourism impacts faced by common dolphins in the Hauraki Gulf are similar to those previously reported for bottlenose dolphins, a coastal species typically considered to be more susceptible to cumulative anthropogenic impacts. This is consistent with a parallel study that also suggests New Zealand common dolphins are equally vulnerable to inshore pollution (Stockin et al. 2007). We recommend the management agency responsible for marine mammal conservation in New Zealand take action to minimise the tourism impacts highlighted by this study. We strongly advocate a moratorium on further permits targeting common dolphins in New Zealand waters, at least until this population has been reassessed and any potential effects of the second permit have been determined.

Acknowledgements. This project was funded by the One World Challenge (America's Cup 2002) and additionally supported by the Institute of Natural Resources (INR) Massey University, Whale and Dolphin Adoption Project (WADAP), Mercury Power New Zealand Ltd., Gulfland Marine Ltd, Gulf Harbour Marina and the Biscay Dolphin Research Programme (BDRP). K.A.S is supported by an Association of Commonwealth Universities (ACU) doctoral scholarship. D.L 
is supported by a Killam postdoctoral fellowship. We acknowledge Auckland's Whale and Dolphin Safari, especially the late S. Stembridge, M. Drascovitch and W. Goodfellow, and particularly thank skippers K. Algie, D. Mares, A. Wiseman, A. Light and J. Keane for their co-operation. Final thanks are owed to the numerous research assistants whose dedicated efforts in the field and laboratory contributed greatly to this research project. We thank the 3 anonymous reviewers whose constructive comments improved earlier drafts of this manuscript.

\section{LITERATURE CITED}

Altmann J (1974) Observational study of behavior: sampling methods. Behaviour 49:227-267

Bain DE, Smith JC, Williams R, Lusseau D (2006) Effects of vessels on behavior of southern resident killer whales (Orcinus orca). NMFS (US National Marine Fisheries Service) Contract Report No. AB133F03SE0959 and AB133F04CN0040 (in press)

Barr K, Slooten E (1999) Effects of tourism on dusky dolphins (Lagenorhynchus obscurus) at Kaikoura, New Zealand. Conservation Advisory Science Notes: 229. Department of Conservation, Wellington

Bejder L, Dawson SM, Harraway JA (1999) Responses by Hector's dolphins to boats and swimmers in Porpoise Bay, New Zealand. Mar Mamm Sci 15:738-750

Bejder L, Samuels A, Whitehead H, Gales N (2006a) Interpreting short-term behavioural responses to disturbance within a longitudal perspective. Anim Behav 72: 1149-1158

Bejder L, Samuels A, Whitehead H, Gales N and others (2006b) Decline in the relative abundance of bottlenose dolphins exposed to long-term disturbance. Conserv Biol 20:1791-1798

Blumstein DT (2004) The emergence of conservation behaviour. Conserv Biol 18:1175-1177

Boggs CL (1992) Resource allocation: exploring the connection between foraging and life history. Funct Ecol 6:508-518

Brault S, Caswell H (1993) Pod-specific demography of killer whales (Orcinus orca). Ecology 74:1444-1454

Burgess EA (2006) Foraging ecology of common dolphins (Delphinus sp.) in the Hauraki Gulf, New Zealand. MSc thesis, Massey University, Auckland

Clua E, Grosvalet F (2001) Mixed-species feeding aggregation of dolphins, large tunas and seabirds in the Azores. Aquat Living Resour 14:11-18

> Coltman DW, O'Donoghue P, Jorgenson JT, Hogg JT, Strobeck C, Festa-Bianchet M (2003) Undesirable evolutionary consequences of trophy hunting. Nature 426:655-658

Constantine R (2001) Increased avoidance of swimmers by wild bottlenose dolphins (Tursiops truncatus) due to longterm exposure to swim-with-dolphin tourism. Mar Mamm Sci 17:689-702

Constantine R, Brunton DH, Dennis T (2004) Dolphin-watching tour boats change bottlenose dolphin (Tursiops truncatus) behaviour. Biol Conserv 117:299-307

Corkeron PJ (1995) Humpback whales (Megaptera novaeangliae) in Hervey Bay, Queensland; behaviour and responses to whale-watching vessels. Can J Zool 73: 1290-1299

Donoghue M (1996) The New Zealand experience-one country's response to cetacean conservation. In: Simmonds MP, Hutchinson JD (eds) The conservation of whales and dolphins: science and practice. John Wiley and Sons, New York, NY, p 423-445

Fleiss JL (1981) Statistical methods for rates and proportions, John Wiley \& Sons, New York, NY

Fujiwara M, Caswell H (2001) Demography of the endangered North Atlantic right whale. Nature 414:537-541

Gaskin DE (1968) Distribution of Delphinidae (Cetacea) in relation to sea surface temperatures off Eastern and Southern New Zealand. N Z J Mar Freshw Res 2:527-534

Gaskin DE (1992) Status of the common dolphin, Delphinus delphis, in Canada. Can Field Nat 106:55-63

> Gerrodette T, Forcada J (2005) Non-recovery of two spotted and spinner dolphin populations in the eastern tropical Pacific Ocean. Mar Ecol Prog Ser 291:1-21

Gordon G, Leaper R, Hartley FG, Chappell O (1992) Effects of whale-watching vessels on the surface and underwater acoustic behaviour of sperm whales off Kaikoura, New Zealand. Department of Conservation, Wellington

Guttorp P (1995) Stochastic modelling of scientific data. Chapman \& Hall, New York, NY

Higgins JJ, Keller-McNulty S (1995) Concepts in probability and stochastic modelling, Duxbury Press, Pacific Grove, CA

Higham J, Lusseau D (2004) Ecological impacts and management of tourist engagements with marine mammals. In: Buckley R (ed) Environmental impacts of ecotourism. CAB International Publishing, Wallingford, p 173-188

Hill MF, Caswell H (2001) The effects of habitat destruction in finite landscapes: a chain binomial metapopulation model. Oikos 93:321-331

Hoyt E (2001) Whale watching 2001: worldwide tourism numbers, expenditures, and expanding socioeconomic benefits. International Fund for Animal Welfare, Yarmouth Port, MA

Lusseau D (2003a) Effects of tour boats on the behavior of bottlenose dolphins: using Markov chains to model anthropogenic impacts. Conserv Biol 17:1785-1793

Lusseau D (2003b) Male and female bottlenose dolphins Tursiops spp. have different strategies to avoid interactions with tour boats in Doubtful Sound, New Zealand. Mar Ecol Prog Ser 257:267-274

Lusseau D (2004) The hidden cost of tourism: detecting longterm effects of tourism using behavioural information. Ecology and Society 9(1):2. Available at: www.ecologyandsociety.org/vol9/iss1/art2/

Lusseau D (2005) Residency pattern of bottlenose dolphins Tursiops spp. in Milford Sound, New Zealand, is related to boat traffic. Mar Ecol Prog Ser 295:265-272

Mann J (2000) Unraveling the dynamics of social life. In: Mann J, Connor RC, Tyack P, Whitehead H (eds) Cetacean societies - field studies of dolphins and whales. The University of Chicago Press, Chicago, IL, p 45-64

Markov AA (1906) Extension of the law of large numbers to dependent events. Bull Soc Phys Math Kazan 15:255-261 (in Russian)

Neumann DR (2001a) The activity budget of free-ranging common dolphins (Delphinus delphis) in the northwestern Bay of Plenty, New Zealand. Aquat Mamm 27:121-136

Neumann DR (2001b) Seasonal movements of short-beaked common dolphins (Delphinus delphis) in the north-western Bay of Plenty, New Zealand: influence of sea surface temperatures and El Niño/La Niña. N Z J Mar Freshw Res 35:371-374

Neumann DR, Orams MB (2003) Feeding behaviours of shortbeaked common dolphins, Delphinus delphis, in New Zealand. Aquat Mamm 29:137-149 
Neumann DR, Orams MB (2006) Impacts of ecotourism on short-beaked common dolphins, Delphinus delphis, in Mercury Bay, New Zealand. Aquat Mamm 32:1-9

Neumann DR, Leitenberger AA, Orams MB (2002) Photoidentification of short-beaked common dolphins, Delphinus delphis, in north-east New Zealand: a photo-catalogue of recognisable individuals. N Z J Mar Freshw Res 36:593-604

O'Callaghan TM, Baker CS (2002) Summer cetacean community, with particular reference to Bryde's whales, in the Hauraki Gulf, New Zealand. DOC Science International Series: 55. Department of Conservation, Wellington

Orams MB (2003) An overview of the industry and its management. In: Garrod B, Wilson AC (eds) Marine ecotourism: issues and experiences. Channel View Publications, London, p 233-248

Orams MB (2004) Why dolphins may get ulcers: Considering the impacts of cetacean based tourism in New Zealand. Tourism Mar Environ 1:17-28

Owen W, Owen P (1999) Hauraki Gulf - a fishing and cruising guide. David Bateman, Auckland

Richter C, Dawson S, Slooten E (2006) Impacts of commercial whale watching on male sperm whales at Kaikoura, New Zealand. Mar Mamm Sci 22:46-63

Scarpaci C, Bigger SW, Corkeron PJ, Nugegoda D (2000) Bottlenose dolphins (Tursiops truncatus) increase whistling in the presence of 'swim-with-dolphin' tour operations. J Cetacean Res Manag 2:183-185

Scarpaci C, Dayanthi N, Corkeron PJ (2003) Compliance

Editorial responsibility: Matthias Seaman,

Oldendorf/Luhe, Germany with regulation by 'swim-with-dolphins' operations in Port Phillip Bay, Victoria, Australia. Environ Manag 31: 342-347

Schaffar-Delaney A (2004) Female reproductive strategies and mother-calf relationships of common dolphins (Delphinus delphis) in the Hauraki Gulf, New Zealand. MSc thesis, Massey University, Auckland

Senata E (1966) Quasi-stationary distributions and timereversions in genetics. J Roy Stat Soc B 28:253-277

Shane SH, Wells RS, Würsig B (1986) Ecology, behavior and social organization of the bottlenose dolphin: a review. Mar Mamm Sci 2:34-63

Stockin KA, Law RJ, Duignan PJ, Jones GW and others (2007) Trace elements, PCBs and organochlorine pesticides in New Zealand common dolphins (Delphinus sp). Sci Total Environ 387:333-345

Werner P, Caswell H (1977) Population growth rates and age versus stage distribution models for teasel (Dipsacus sylvestris). Ecology 58:1103-1111

Williams R, Trites AW, Bain D (2002) Behavioural responses of killer whales (Orcinus orca) to whale-watching boats: opportunistic observations and experimental approaches. J Zool (Lond) 256:255-270

Williams R, Lusseau D, Hammond PS (2006) Estimating relative energetic costs of human disturbance to killer whales (Orcinus orca). Biol Conserv 133:301-311

Würsig B (1986) Delphinid foraging strategies. In: Schusterman RJ, Thomas JA, Wood FG (eds) Dolphin cognition and behavior: a comparative approach. Lawrence Erlbaum Associates, Hillsdale, NJ, p 347-359

Submitted: May 15, 2007; Accepted: December 20, 2007 Proofs received from author(s): February 2, 2008 